\title{
Modelling the runoff, nutrient and sediment loadings in the Torrens river catchment, South Australia using SWAT
}

\author{
$\underline{\text { H.H.Nguyen }}^{\text {a }}$, F.Recknagel ${ }^{\mathrm{a}}$, W.Meyer ${ }^{\mathrm{a}}$ \\ ${ }^{a}$ School of Biological Sciences, Faculty of Science, University of Adelaide, South Australia \\ Email: hanh.nguyen@adelaide.edu.au
}

\begin{abstract}
Torrens River is situated in the most populated catchment of Adelaide, South Australia. Over the past several decades the lower part of the catchment has been heavily altered by urbanization that has impacted the water quality of Torrens streams. Recurrent algal blooms along the river are driven both by stormwater runoff and in-stream pollutants. This study aims to estimate the loadings of nutrients and sediments of the urban section of Torrens river catchment (also known as Karrawirra Parri Prescribed Watercourse) between 2007 and 2016. This part of the river initially receives water from the Gorge weir and its flow is swelling by urban tributaries downstream. The Soil and Water Assessment Tool (SWAT) has been applied to develop a comprehensive model by integrating all available data on weather, soil, land use, hydrology and water quality in the catchment. The data from 2007 to 2009 were used as a "warm-up" period. The model has been calibrated from 2010 to 2013 for the main stream and one creek site. The calibrated model has been validated for the main stream from 2014 to 2015 as well as for tributaries that have been spatially-explicit monitored from 2015 to 2016. The results indicate that the model simulates reasonably well the runoff and nutrient loadings whilst results for sediment loadings are less satisfactory. The reasons behind these shortcomings are analyzed, taking into account the length and quality of available data records. The results obtained from this case study suggest that SWAT is an effective tool for simulating the long-term characteristics of surface runoff of urbanized semiarid catchments, and can assist in estimating nutrient loadings of the main stream and tributaries. The validated model is currently tested as a tool for simulating prospective effects of future land use and climate changes.
\end{abstract}

Keywords: Catchment modelling, River Torrens, runoff, nutrients, sediment, SWAT 


\section{INTRODUCTION}

Rapid urbanization can result in numerous negative effects on river catchments. Urbanization increases the area of impermeable surfaces and causes rivers to be regulated by dams and sluices (Zang et al., 2013). Urbanization also affects the process of pollutant migration and transformation, and significantly speeds up the elevation rate of pollutant concentrations in river catchments (Whitehead et al., 2002). Studies in Australia, the United States and South Africa have shown significant correlations between modified flow regimes and decreasing river water quality (Boon and Ravel, 2012). Sustainable management of highly urbanized catchments has to take into account spatial and temporal variations of both water quantity and quality.

To examine the status of water quality as well as the source and fate of pollutants in river catchments, continuous monitoring is considered to be the most efficient method (Ilman and Gell, 1998). Whilst water quality monitoring is a robust approach for operational catchment assessment, resulting data rarely comprehend all stream sites and are disconnected from meteorological, soil and land use data. In this regard, catchment modelling is an ideal supplementary tool. Catchment modelling allows to integrate all sources of relevant information and develops dynamic models that simulate past and present conditions of catchments. Among existing rainfall-runoff and water quality modelling, the Soil and Water Assessment Tool (SWAT) is a wellknown process-based semi-distributed model that applies at river catchment scale (e.g. Gassman et al., 2007; Neitsch et al., 2011). However, applications of the SWAT to Australian catchments are still limited (Saha and Zeleka, 2015), especially for in-stream water quality parameters.

This study applies SWAT to the River Torrens catchment in South Australia (SA). This is a typical regulated catchment with high density of urban population that accounts for over three quarter of the State's population (Brookes 2012). The study calibrates SWAT on the basis of data at gauged stations and tests the applicability of this model for simulating the runoff, nutrient (TN, TP) and suspended solid (TSS) loadings for ungauged streams within the catchment. Furthermore, the validated model estimates the contribution of pollutant loadings from major creeks along the river to determine the potential hot-spots. The preliminary output of this study will provide useful information for managing the urban water quality and assisting the development of the Water Sensitive Urban system.

\section{MATERIALS AND METHODS}

\subsection{Study area}

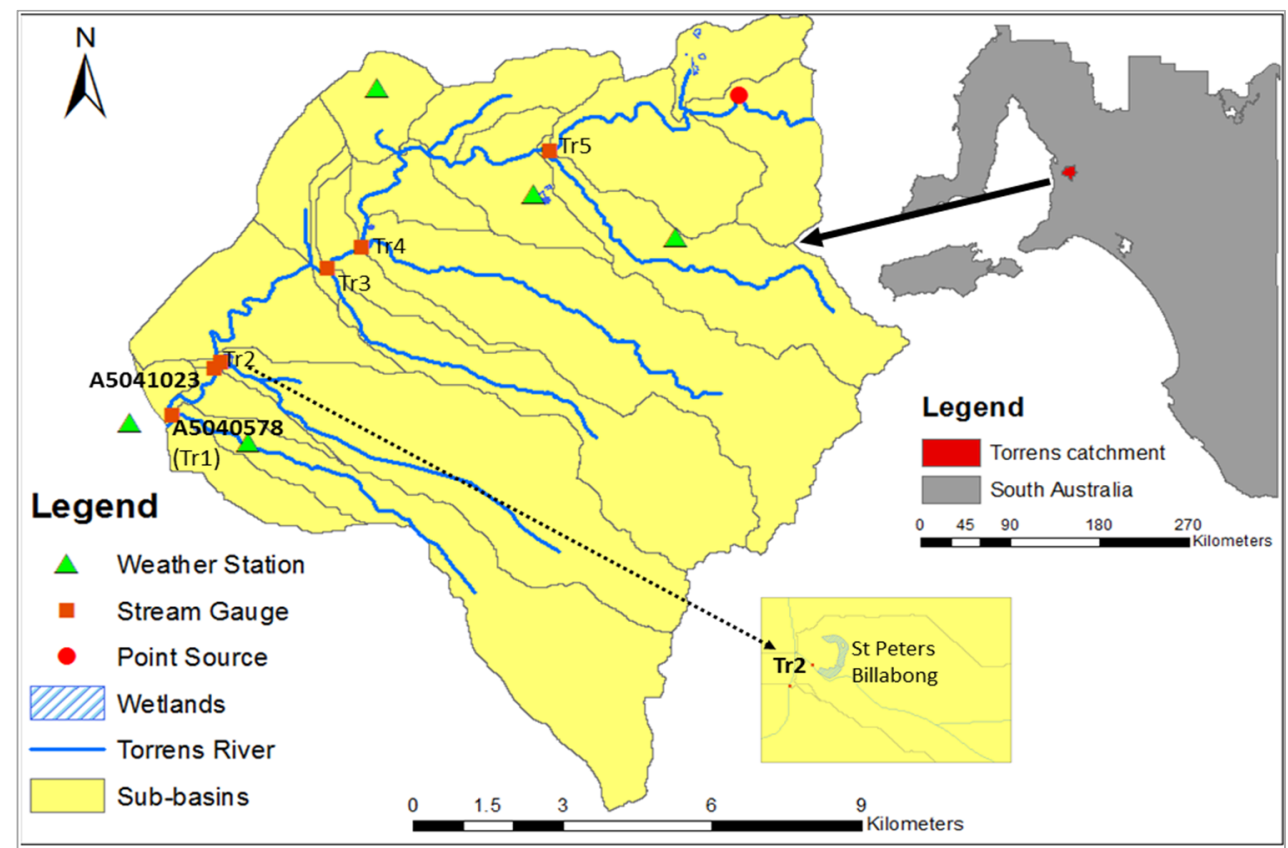

Figure 1. Locations of the urban River Torrens catchment and monitoring stations

The urbanized section of River Torrens catchment drains an area of approximately $200 \mathrm{~km}^{2}$. It is separated from the upper rural catchment at Gorge weir (Figure 1). The flow continues through the five major Creeks and ends at the inlet to the artificial Torrens Lake in the center of Adelaide city. The catchment is fed by urban stormwater and environmental flow releases from upstream reservoirs. The urban Torrens serves multiple roles for the city, including the supply of an environmental flow for the Adelaide Plains and helps in preserving the 
recreational and conservational values of Adelaide city (Gale et al., 2006). The catchment experienced a heavy modification, especially at its lower creeks due to the pressure from demands for urban development. Phosphate and nitrate concentrations at certain periods of the year exceeded national guidelines and the river was classified as hypereutrophic (Forsberg and Ryding, 1980). A cyanobacterial bloom in the River Torrens in 1998 has drawn considerable publicity, and since then blooms recurred periodically although many management approaches have been applied (Illman and Gell, 1998; Brookes, 2012). The blooms have been linked to the release and accumulation of pollutants within the catchment.

\subsection{Input data}

Input data include elevation, land use and soil maps as well as meteorological and water quality data. The $10 \times 10$ m contour was interpolated to prepare the Digital Elevation Model (DEM) for the study. The 2007 landuse map classifies the urban Torrens into residential, commercial, institutional, industrial, transportation, water, and park lands. A soil map $(1: 100,000)$ of the urban Torrens was provided by SA Department of State Development meanwhile the database of nine soil categories was constructed on the basis of available data from Australian Soil Resources Information, Drill Core Reference Library as well as expert knowledges. Weather data (including maximum and minimum air temperature, rainfall, relative humidity, and solar radiation) was imported in the model using daily records from the Scientific Information for Land owners (SILO). Long-term data records of two gauged stations were provided by SA Water Corporation and SA Department of Environment, Water and Natural resources. This study also uses the in-situ monitoring data near the outlets of four among five creeks along urban Torrens which were collected during the sampling campaign from 2015 to 2016. Observed records at the Second Creek were not used for modelling because the flow at this site was periodically switch on and off from the main system following the adjustment in the management practices.

Table 1. Description of monitoring data along the River Torrens catchment

\begin{tabular}{|c|c|c|c|c|}
\hline Name & Monitoring sites & Latitudes & Longitudes & Data availability \\
\hline A5041023 & Torrens downstream the Second Creek & $34^{\circ} 54^{\prime} 24.31^{\prime \prime}$ & $138^{\circ} 36^{\prime} 52.31^{\prime \prime}$ & $\begin{array}{l}\text { Continuous daily } \\
\text { data of runoff; } \\
\text { Weekly to monthly }\end{array}$ \\
\hline $\begin{array}{c}\text { A } 5040578 \\
(\operatorname{Tr} 1)\end{array}$ & Torrens at First Creek & $34^{\circ} 54^{\prime} 55.44^{\prime \prime}$ & $138^{\circ} 36^{\prime} 22.68^{\prime \prime}$ & $\begin{array}{l}\text { data from } \\
\text { composite samples } \\
\text { of TN, TP, and } \\
\text { TSS (2007-2015) }\end{array}$ \\
\hline $\operatorname{Tr} 2$ & Second Creek (near St Peters Billabong) & $34^{\circ} 54^{\prime} 24.20^{\prime \prime}$ & $138^{\circ} 36^{\prime} 52.86^{\prime \prime}$ & \multirow{4}{*}{$\begin{array}{l}\text { Monthly grab } \\
\text { samples data of } \\
\text { runoff, TN, TP, } \\
\text { and TSS (2015- } \\
2016)\end{array}$} \\
\hline $\operatorname{Tr} 3$ & Third Creek & $34^{\circ} 53^{\prime} 16.78^{\prime \prime}$ & $138^{\circ} 38^{\prime} 25.59^{\prime \prime}$ & \\
\hline $\operatorname{Tr} 4$ & Fourth Creek & $34^{\circ} 52^{\prime} 59.76^{\prime \prime}$ & $138^{\circ} 39^{\prime} 7.82^{\prime \prime}$ & \\
\hline $\operatorname{Tr} 5$ & Fifth Creek & $34^{\circ} 51^{\prime} 58.07^{\prime \prime}$ & $138^{\circ} 41^{\prime} 21.29^{\prime \prime}$ & \\
\hline
\end{tabular}

\subsection{Model set-up}

The SWAT model (ArcSWAT version 2012) was used to simulate the flow, TN, TP and TSS loadings at a monthly time step. The model was originally developed to predict the effects of land management practices on water, sediment and chemical yields in river catchments and has constantly been updated and applied to case studies worldwide.

The SWAT runs in continuous mode and was simulated at a monthly time step. The study area was divided into 23 sub-catchments based on the topography map to account for the spatial variability in the catchment. Sub-catchments were further subdivided into 125 Hydrologic Response Units (HRUs) using unique combinations of land uses, soil types, and slopes characteristics (Neitsch et al., 2011). Surface runoff was calculated using a modification of the Soil Conservation Service (SCS) curve number technique. The sediment simulation is based on the Modified Universal Soil Loss Equation (MUSLE); whereas, TN and TP parameters were calculated and then routed in streams using the QUAL2E model (Winchell et al., 2013). Management practices were adjusted considering local land use operations on the basis of experts' knowledge. Specifically, all operations were scheduled by their application date rather than by heat unit (Neitsch et al., 2011). The growing season for Eucalyptus forest, pastures and urban plants (Bermuda grass) were scheduled from June 1 to May 30. Forests and pastures were not fertilized; meanwhile fertilizer application rate was scheduled with 
$50 \mathrm{~kg} \mathrm{~N}$ and $6 \mathrm{~kg}$ P for pasture. Auto-irrigation was scheduled for urban grass land with the rate of $1 \mathrm{~mm}$ at the top soil layer.

In this study, the model was first calibrated consecutively for flow, sediment and lastly for TN and TP parameters using Sequential Uncertainty Fitting version 2 (SUFI2) (Abbaspour et al., 2004) of SWAT Calibration and Uncertainty program (SWAT-CUP) (Abbaspour, 2015). SUFI2 was selected because of the high efficiency and accuracy in calibration. Three years of 2007, 2008, and 2009 was preserved as warm-up period for the model stabilization. The calibration started from 2010 till 2013 while validation was performed for the two years of 2014 and 2015. The performance of model optimization was judged on the basis of graphical, statistical, and uncertainty analysis. The correlation coefficient $\left(\mathrm{R}^{2}\right)$, Nash-Sutcliffe (NS), and percent bias (PBIAS) were used for evaluation of runoff simulation with a threshold for $\mathrm{R}^{2}$ and NS greater than 0.5 , and percent bias (PBIAS) ranged between $\pm 25 \%$ (Moriasi et al., 2007). In case of TN, TP, and TSS, due to the uncertainty of the quality of composite samples, the simulation was considered satisfactory when achieving the graphical match of the observed and simulated data and the PBIAS value within the range $\pm 70 \%$ (Lee et al., 2015).

\section{RESULTS AND DISCUSSION}

The results of calibration were successful in terms of overall adequate representation of the observed runoff. This is highlighted by the very good $\mathrm{R}^{2}$ of 0.92 and 0.92 , NS of 0.90 and 0.91 , and PBIAS of 5.6 and -13.5 for the calibration and validation at the main stream stations A5041023, respectively. Results of runoff simulation was also satisfactorily good at the creek station A5040578 with $\mathrm{R}^{2}$ of 0.77 and 0.93 , NS of 0.75 and 0.93 , and PBIAS 1.8 and -11.4 for calibration and validation, respectively. The results from this study confirm that the SWAT has a promising scope to explain the hydrology of semi-arid climate regions which particularly applies to South Australian catchments (Saha and Zeleka, 2015; Nguyen et al., 2017).

Outputs for nutrient loadings' simulation met the satisfactory threshold, too, as shown by the graphical match and the calibrated values of PBIAS which varied from -55.6 to -0.9 for TN and 34.2 to 69.4 for TP at the two gauging stations. The validation results were even better with all three parameters gaining the satisfactory level (Figure 2), except TP at the First Creek (station A5040578). This is partly explained due to the effect of fertilizer and pesticide applications at the Botanic Gardens which is located upstream of the gauging station (Figure 1). TSS however, was significantly underestimated at both stations (Figure 2). This represents the missing information in the model representation of potential impact sources in the catchment which might be associated with unknown releases from the industrial quarries discharge.
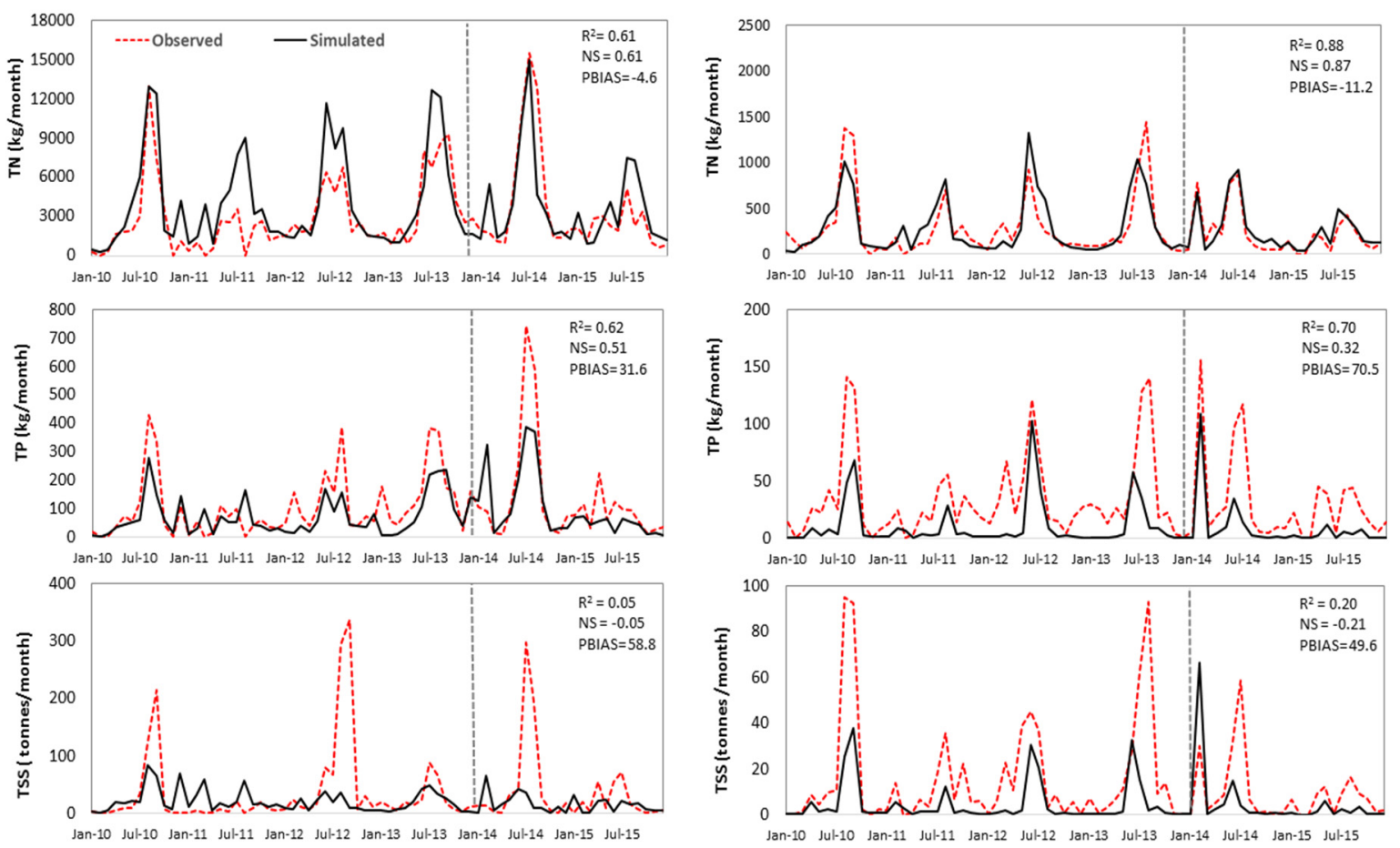

Figure 2. Results of Total Nitrogen (TN), Total Phosphorous (TP), and suspended solids (TSS) calibration at Torrens downstream Second Creek (left hand graphs) and First Creek (right hand graphs) 
The sensitive parameters for TN, TP, and TSS calibrations are summarized in Table 2 . The 20 most sensitive parameters were selected on the basis of literature review and were confirmed through the global sensitivity test (Abbaspours, 2015). The three most sensitive parameters for water quality calibration include 'Denitrification threshold water content' (SDNCO), 'USLE equation soil erodibility (K) factor' (USLE_K), and 'Channel erodibility factor' (CN_COV1). All calibrated data were well in range of the model default and no extreme values were recorded.

Table 2. Parameters used for model calibration and validation of nutrient and TSS loadings

\begin{tabular}{|c|c|c|c|c|}
\hline No. & Parameter & Description & Initial ranges & Calibrated ranges \\
\hline 1 & CH_COV1 & Channel erodibility factor & {$[0.05,0.6]$} & {$[0.21,0.54]$} \\
\hline 2 & SPCON & $\begin{array}{l}\text { Linear parameter for calculating the } \\
\text { maximum amount of sediment that can be } \\
\text { re-entrained during channel sediment } \\
\text { routing }\end{array}$ & {$[0.0001,0.01]$} & {$[0.001,0.006]$} \\
\hline 3 & SPEXP & $\begin{array}{l}\text { Exponent parameter for calculating } \\
\text { sediment re-entrained in channel sediment } \\
\text { routing }\end{array}$ & {$[1,1.5]$} & {$[1.04,1.35]$} \\
\hline 4 & USLE_P & USLE equation support practice factor & {$[0,1]$} & {$[0.48,0.51]$} \\
\hline 5 & USLE_K & USLE equation soil erodibility $(\mathrm{K})$ factor & {$[0,0.65]$} & {$[0.22,0.65]$} \\
\hline 6 & DIRTMX & $\begin{array}{l}\text { Maximum amount of solids allowed to } \\
\text { build up on impervious area }\end{array}$ & {$[0,2000]$} & {$[765,1295]$} \\
\hline 7 & URBCOEF & $\begin{array}{l}\text { Wash-off coefficient for removal of } \\
\text { constituents form impervious area }\end{array}$ & {$[0,1]$} & {$[0.47,0.51]$} \\
\hline 8 & TNCONC & $\begin{array}{l}\text { Concentration of total nitrogen in } \\
\text { suspended solid load from impervious area }\end{array}$ & {$[0,1000]$} & {$[152,718]$} \\
\hline 9 & TPCONC & $\begin{array}{l}\text { Concentration of total phosphorus in } \\
\text { suspended solid load form impervious area }\end{array}$ & {$[0,1000]$} & {$[140,714]$} \\
\hline 10 & NPERCO & Nitrogen percolation coefficient & {$[0,1]$} & {$[0.44,0.83]$} \\
\hline 11 & $\mathrm{CDN}$ & Denitrification exponential rate coefficient & {$[0,3]$} & {$[0.29,1.90]$} \\
\hline 12 & SDNCO & Denitrification threshold water content & {$[0,1]$} & {$[0.06,0.69]$} \\
\hline 13 & ERORGN & Organic nitrogen enrichment ratio & {$[0,5]$} & {$[1.17,3.72]$} \\
\hline 14 & LAT_ORGN & Organic $\mathrm{N}$ in the base-flow & {$[0,200]$} & {$[87.1,104.3]$} \\
\hline 15 & PSP & Phosphorus sorption coefficient & {$[0.01,0.7]$} & {$[0.19,0.58]$} \\
\hline 16 & BC4_BSN & $\begin{array}{l}\text { Rate constant for decay of organic } \\
\text { phosphorus to dissolved phosphorus }\end{array}$ & {$[0.01,0.7]$} & {$[0.10,0.43]$} \\
\hline 17 & PHOSKD & Phosphorus soil partitioning coefficient & {$[100,200]$} & {$[61.84,153.96]$} \\
\hline 18 & PERCOP & Pesticide percolation coefficient & {$[0,1]$} & {$[0.26,0.78]$} \\
\hline 19 & ERORGP & Organic phosphorus enrichment ratio & {$[0,5]$} & {$[0.63,3.54]$} \\
\hline 20 & RS5 & $\begin{array}{l}\text { Organic phosphorus settling rate in the } \\
\text { reach at } 20^{\circ} \mathrm{C}\end{array}$ & {$[0.001,0.1]$} & {$[0.01,0.06]$} \\
\hline
\end{tabular}

Basing on the outputs of the calibration step, the best calibrated parameters of the station A5041023 were applied for validating the data at creek sites along the urban Torrens (Figure 1, Figure 3), except the First Creek that located downstream from the main station and thus was calibrated independently. It is assumed that calibrated parameters at the main outlet can be applied to all sites in the upstream area of the catchment. For this practice, the on-site monitoring data of 2016 was used for validation. Results suggested that observed TN loadings are reasonably well represented by the SWAT simulations at all creeks (Figure 3). The validated results of TP confirmed the underestimation of the model at the First Creek while at other sites the observed and simulated results agreed relatively well. Again, the simulated results at the Second Creek were not presented in this study because this site was affected by the runoff from the St Peters Billabong (Figure 1) which was connected to the stream site sometime during the period of the study. Overall, the model indicates that the rate of nutrient loadings released from creeks are relatively low, which varied from 672 to 1,287 $\mathrm{kg} /$ month and from 0.90 to $17.59 \mathrm{~kg} /$ month for TN and TP, respectively. 

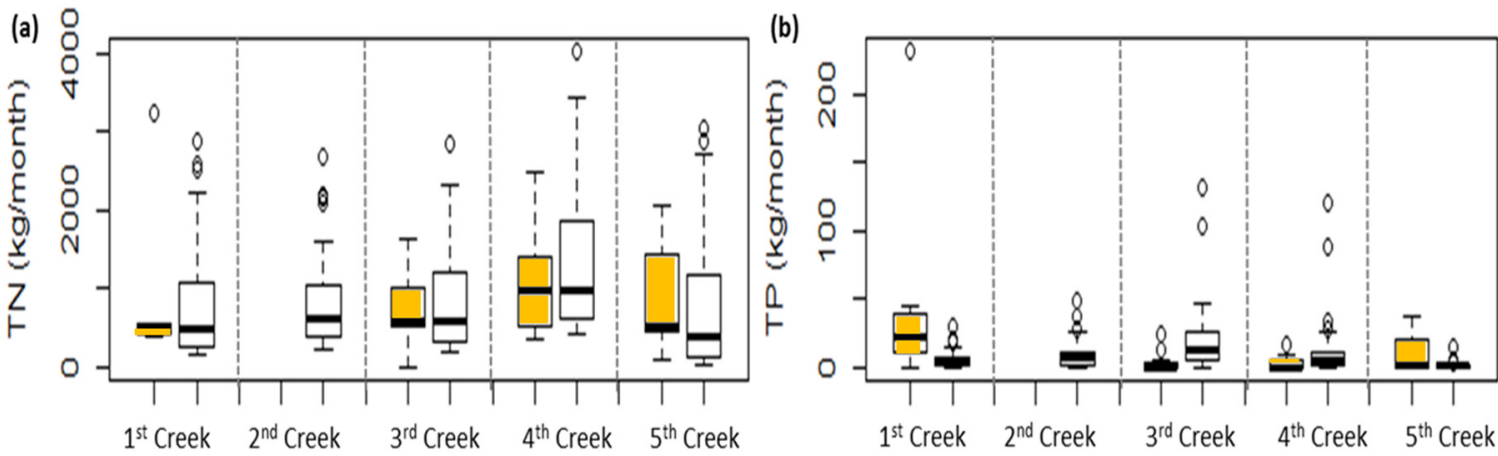

Figure 3. Box plots of observed and simulated (a) TN and (b) TP loadings at in-situ monitoring sites near the outlets of five creeks along the River Torrens catchment.

Note: The first box plot in each column represents data of observed grab samples and the second one is the SWAT loadings' estimation.

Further, the calibrated SWAT model was applied to estimate the nutrients release from all tributaries to define potential hotspots. The simulated TN and TP loadings from the outlets along the urban River Torrens catchment normalized by catchment size are illustrated in Figure 4. The results suggest that the Second Creek site, if remains disconnected from the St Peters Billabong, does not contribute significant loading of nutrients into River Torrens. Normalized TN loadings from other creeks however indicated a higher discharge than the loadings from the main stream, with the highest TN rate at Fifth Creek of $710 \mathrm{~kg} / \mathrm{km}^{2} /$ year and followed by slightly lower rates at Third and Fourth Creeks. This can be explained due to the fact that the Fifth Creek contributes highest inflow into River Torrens in comparison to other intermittent creeks. In case of TP loadings, the discharge from all sites ranged from 0.89 to $14.7 \mathrm{~kg} / \mathrm{km}^{2}$ which is well below the rate at the main stream of $16.4 \mathrm{~kg} / \mathrm{km}^{2}$. However, the TP released from Third Creek seems to be affected by the discharge from the local horticulture activities and industries, which include the stormwater release from concrete manufacturing.
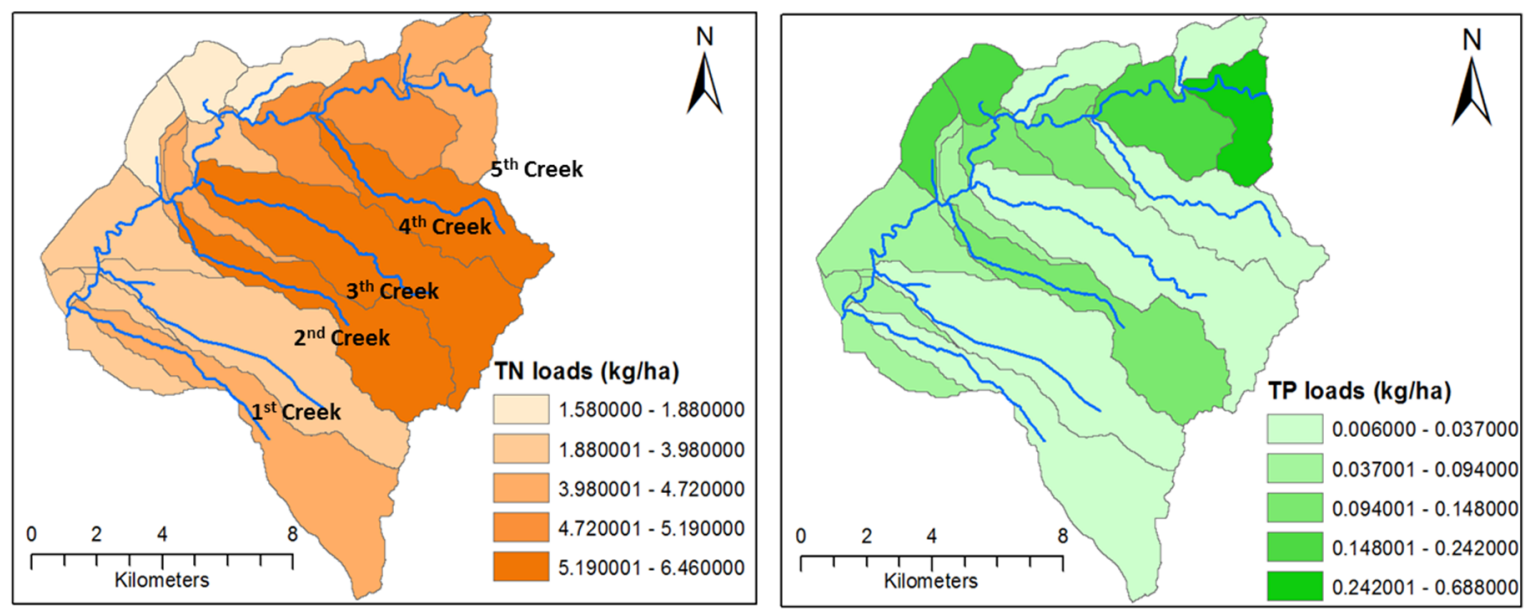

Figure 4. Simulated TN and TP loadings normalized by catchment size in the urban River Torrens catchment in period from 2007 to 2015 .

\section{CONCLUSIONS}

The analysis of water quality condition of the urban Torrens catchment was performed by means of the processbased model SWAT. The model showed a very good results in simulating flow, both at the main stream and creek sites. Despite some limitations of the available input, the SWAT proved to be a promising candidate model for estimating the TN loadings. The TP loadings also met the satisfactory criteria, except the case at one creek. However, TSS loadings were significantly underestimated at all creeks which suggest the lack of important point sources contribution. Overall, results from this modelling indicate that the nutrient loadings in the Torrens catchment remains low over the years but the effects come both from the creek sites and the main reach. Thus any management practices on controlling and reducing the nutrients level need to consider the catchment as a whole rather than focusing on any particular sites. Results from this study prove that SWAT is a useful tool for analysis of hydrology and can assist in better understanding the fate and transport of nutrient loadings into catchments. Future research will build on outcomes of this study with a focus on evaluating 
Nguyen et al., Modelling the runoff, nutrient and sediment loadings in the Torrens river

effects of climate and land use changes by means of scenario analysis. The urban population of this region is projected to increase significantly by 2050 which will cause further impacts of urbanization. Meanwhile, global warming with higher temperature and less rainfall will also threaten the intermittent urban creeks' ecosystem.

\section{ACKNOWLEDGMENTS}

The study is funded by the South Australian Water Corporation and the Department of Environment, Water and Natural Resources. We would like to acknowledge the abovementioned organizations for data supports to this work. A special thanks to Mr. Malcolm Sheard for his professional advices on the preparation of soil data for the study.

\section{REFERENCES}

Abbaspour, K.C. (2015). SWAT-CUP: SWAT Calibration and Uncertainty Programs-A User Manual. Eawag: Dübendorf, Switzerland, 16-70.

Abbaspour, K.C., Johnson, C., van Genuchten, M.T. (2004). Estimating uncertain flow and transport parameters using a sequential uncertainty fitting procedure. Vadose Zone Journal, 3 (4), 1340-1352.

Boon, P.J. and Ravel, P.J. (2012). River Conservation and Management. John Wiley, Chichester, 428 pp.

Brookes, J.D. (2012). River Torrens Water quality improvement trial - Summer 2011/12'. Goyder Institute for Water Research Technical report, 12(4), 116 pp.

Forsberg, C. and Ryding, S.O. (1980). Eutrophication parameters and trophic status indices in 30 Swedish waste receiving lakes. Hydrobiologia, 89, 189-207.

Gale, R.J.B., Gale, S.J., and Winchester, H.P.M. (2006). Inorganic pollution of the sediments of the River Torrens, South Australia. Environmental Geology, 50, 62-75.

Gassman, P.W., Reyes, M.R., Green, C.H., and Arnold, J.G. (2007). The Soil and Water Assessment Tool: Historical development, applications and future research directions. Transaction of ASAE (Am. Soc. Agric. Eng.), 50, 1211-1250.

Ilman, M.A. and Gell, P.A. (1998). Sediments, Hydrology and Water Quality of the River Torrens: A Modern and Historical Perspectives. Three Projects for the River Torrens Water Catchment Management Board. Department of Geographical and Environmental Studies, University of Adelaide, 10-53.

Lee, T., Wang, X., White, M., Tuppad, M., Srinivasan, R., Narasimhan, B., and Andrews, D. (2015). Modeling Water-Quality Loads to the Reservoirs of the Upper Trinity River Basin, Texas, USA. Water, 7, 5689-5704.

Moriasi, D.N., Arnold, J., Van Liew, M., Bingner, R.L., Harmel, R.D., Veith, T.L. (2007). Model evaluation guidelines for systematic quantification of accuracy in watershed simulations. Transaction of ASAE (Am. Soc. Agric. Eng.), 50, 885-900.

Neitsch, S.L., Arnold, J.G., Kinir, J.R., and Wiliams, J.R. (2011). Soil and Water Assessment Tool: Theoretical Documentation 2009. Technical Report No. 406. Texas Water Resources Institute-Texas A\&M University. College Station, TX, USA, 29-180.

Nguyen, H.H., Recknagel, F., Meyer, W., and Frizenschaf, J. (2017) Analysing the effects of Forest cover and Irrigation farm dams on streamflows of water-scarce catchments in South Australia through the SWAT model. Water, 33(9), 1-16.

Saha, P.P. and Zeleke, K. (2015). Rainfall-Runoff Modelling for Sustainable Water Resources Management: SWAT Model. Review in Australia. In Sustainability of Integrated Water Resources Management. Water Governance, Climate and Ecohydrology (eBook). Setegn, S.G., Donoso, M.C., Eds. Springer International Publishing AG. Cham, Switzerland, 563-578.

Whitehead, P.G., Lapworth, D.J., Skeffington, R.A., and Wade, A. (2002). Excess nitrogen leaching and C/N decline in the Tillingbourne catchment, southern England: INCA process modelling for current and historic time series. Hydrology and Earth System Sciences, 6(3), 455-466.

Zhang, Y., Xia, J., Shao, Q., and Zhai, X. (2013). Water quantity and quality simulation by improved SWAT in highly regulated Huai River Basin of China. Stochastic Environmental Research and Risk Assessment, 27, 11-27. 